Received: 11/07/2018

Revision: 02/11/2018

Accepted: 07/11/2018

OnlineFirst: 15/12/2018

\title{
A Structural Equation Model Describes Factors Contributing Teachers' Job Stress in Primary Schools
}

\author{
Anis Salwa Abdullah \\ Corresponding author, School of Education and Modern Language, Universiti Utara \\ Malaysia, Sintok, Kedah, Malaysia, anis_salwa@ahsgs.uum.edu.my
}

Siti Noor Ismail

PhD, Universiti Utara Malaysia, Sintok, Kedah, Malaysia, siti.noor@uum.edu.my

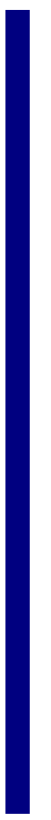

The job stress model was developed by Boyle, Borg, Falzon, and Jr. (1995) with 20 items in five (5) dimensions named workloads, professional recognition, students' misbehaviour, time and resource constraint, as well as peer relationship. A study was carried out later by Collie, Shapka, and Perry (2012) using the same items as proposed by Boyle et al. (1995), with one (1) additional four (4) items dimension named technology. The aim of this particular study was to re-examine and re-confirm that the measurement model for job stress construct with the respective dimensions and items would hold for teachers in the primary schools setting in Kelantan, Malaysia. Thus, this study employed confirmatory factor analysis to achieve the objective. As a result, this study proposed a measurement model which described factors contributing primary school teachers' job stress with eight (8) dimensions, namely T1 (students misbehaviour), T2 (workloads), T3 (professional recognition), T4 (time and resource constraint), T5 (interpersonal relationship), T6 (training and support towards technology), T7 (curriculum facilities and exposure constraints) and T8 (technology literacy). This model evaluated its construct validity by estimating both convergent and discriminant validity, while evaluating the internal consistency of the proposed model itself, and estimates how the instrument determines the reasonable relations among the latent factors mentioned above, and how it describes the reasonable results and assigns the quality of data fit within it. The specific model can be used by researchers to evaluate the effect of different aspects of job stress in the education institutions.

Keywords: job stress, teachers, primary schools, measurement model, stress

\section{INTRODUCTION}

Nowadays, stress becomes an issue among teachers that they are increasingly exposed to the risk of experiencing workload and job stress that can affect work performance, and 
possibly further exacerbating social relationships between colleagues, students and parents. In fact, stress in teaching was one (1) of the factors that influenced the performance of teachers. Stress had an impact on teachers who will ultimately affect students' achievement (Ashikia, 2010; Tahir, 2011). The teachers were more exposed to job-related stress. Thus, the factors that contributed to teacher stress and burnout, if not immediately overcome, could cause serious negative effects (Steinhardt, Jaggars, Faulk, \& Gloria, 2011).

Effective and systematic career training and development opportunities, teacher engagement in decision-making and better working conditions are factors that help teachers work, improve job satisfaction and reduce emotional stress (Anastasiou \& Papakonstantinou, 2014).

Many teachers consider that job stress will significantly impact physical and personal relationships, but teachers identify the importance of human resources and materials to reduce job-related stress (Shernoff, Mehta, Atkins, Torf, \& Spencer, 2011), as well as to address negative impacts and great stress in teaching professionalism as stress on teachers is one of the factors that influence student achievement and school performance (Ashikia, 2010; Tahir, 2011).

Student misbehavior is the most important factor in stress in the school environment. Among the factors that influence and are the main predictors in the work stress of teachers in school are behavioral disruptive behavior that contributed to the highest correlation value (Karaj, 2012; Schaubman, Stetson, \& Plog, 2011; Boyle et al., 1995, Abdul Said Ambotang, Norazizah Pilus \& Andin, 2014; Kamarulzaman Kamaruddin, 2007) stresses and workloads (Boyle et al., 1995), relationships with school administrators, but do not include relationships between colleagues (Karaj, 2012), and teachers' experiences (Azizi Yahaya, Jamaludin Ramli, \& Mazeni Ismail, 2010). In addition, gender and workload also contributed significantly to teachers' mental health status. In fact, teachers with heavy workload have lower mental health (Nurul Izzah Abdul Samad \& Zailina Hashim, 2010).

\section{PURPOSE OF THE STUDY}

The study proposed a measurement model which described factors contributing to job stress among teachers in primary schools and its respective measuring items, such as students' misbehavior, workloads, professional recognition, time and resource constraint, interpersonal relationship, training and support towards technology, curriculum facilities and exposure constraints and technology literacy. The study also tested the proposed model for the convergent and discriminant validity, as well as for its reliability.

\section{METHOD}

\section{Participants}

The respondents were 330 teachers from the excellent-achieving in Primary School Achievement Test schools in Kelantan, Malaysia. The total of $124(37.6 \%)$ were males and $206(62.4 \%)$ were females. As regards the year of teaching, 191 teachers had been 
teaching for 20 to 29 years $(57.90 \%)$. The number of teachers with teaching experience of 10 to 19 years was $72(21.80 \%)$. There were 35 teachers among respondents had been teaching more than 30 years $(10.60 \%)$, while others teaching in less than 10 years are 32 $(9.70 \%)$.

\section{Instrument}

Boyle et al. (1995) developed a 20-item scale to evaluate teachers' job stress and called it Teacher Stress Inventory (TSI). In 2012, Collie et al. (2012) added another 4 items of a new component to the scale. The scale seeks to clarify the job stress dimension of workload, professional recognition, students' misbehaviour, time and resources constraints, peer relationship and technology. More specifically, TWS evaluates the degree to which teachers feel that all the components affect their job stress in schools. The 24 items of TWS items were of an interval type scale and extended from 1 for strongly disagree to 10 for strongly agree.

\section{Data Analyses}

Data had been recoded to ensure its unidimensionality. This job stress model estimation was tested in SEM by AMOS Software through Confirmatory Factor Analysis (CFA) technique. The model estimation was generated using the Maximum Likelihood Estimation (MLE), with the item covariance matrix was being used as an input. The indexes were identified based on their loadings. All the indicators were associated to their respective latent or unobserved variables in calculating the estimate.

\section{FINDINGS}

The questionnaires used in this study were adopted from the previous study. However, the ten-point interval scales questionnaires used in this study consist of eight (8) components, which were T1 students misbehaviours, T2 workloads, T3 professional recognition, T4 time and resources constraints, T5 interpersonal relationship, T6 training and support, T7 facilities and curriculum exposure constraints and T8 technology literacy. These components were derived from EFA analysis that was carried out using the pilot data (Anis Salwa Abdullah \& Siti Noor Ismail, 2018).

This study analysed the measurement model using CFA to determine the meaningfulness of each item in the reflective construct. The first-order reflective measurement model is presented in Figure 1. 


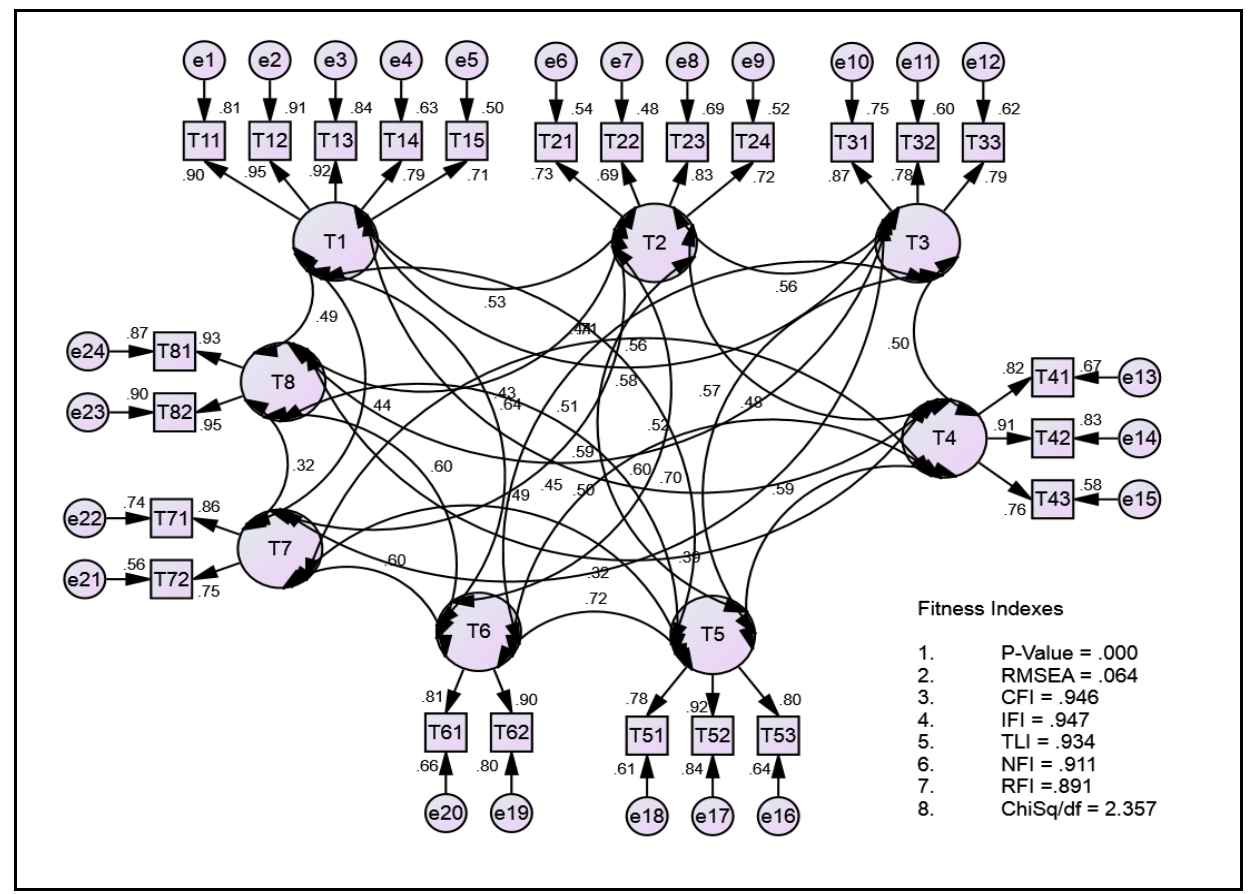

Figure 1

The first-order reflective measurement model

The T1 component contained five (5) questionnaire items namely T11 to T15. The T2 component consisted of four (4) questionnaire items namely T21 to T24, while T3 with three (3) questionnaire items which were T31 to T33. The T4 and T5 component also consisted of three (3) questionnaire items respectively, which were T41 to T43 and T51 to T53. While, the T6, T7 and T8 components contained two (2) questionnaire items accordingly, which were T61 to T62, T71 to T72 and T81 to T82. All the T11 to T82 items were the response items for the job stress construct, while e1 to e 24 were the respective measurement errors of each item.

\section{Unidimensionality}

In the questionnaire, the items of job stress construct in the form of "Are these stress factors affecting you?" used interval 1 (Very Disagree) to scale 10 (Strongly Agree). Thus, if the respondents agreed on these items, the answer was the opposite, because these items were in reverse form. These items were in the form of negative items. Therefore, data from negative items needed to be processed by re-coding from negative data to positive data to maintain its unidimensional in the Recode into Same Variables procedure in SPSS.

Then, the unidimensionality test for the first-order reflective measurement model had been achieved with all the measurement items showed high factor loading values, ranging from 0.69 to 0.95 . The high value of the item factor loadings $(>.60)$ confirmed 
that all the particular items were meaningful in measuring the job stress construct, and thus could be maintained in the model for each component in the construct. This unidimensionality values also showed that all factor loadings indicated positive values and in one (1) direction.

\section{Validity}

The result of the CFA analysis showed that the fitness indexes and factor loadings for every item. The fitness indexes for the model were assessed in the following Table 1. The overall analysis of the model indicated that the model is a very good fit.

Table 1

The fitness indexes for the job stress measurement model

\begin{tabular}{llll}
\hline Category & Index & Index Value & Output \\
\hline Absolute fit & RMSEA $<.08$ & 0.06 & The required level is achieved \\
Incremental fit & CFI $>90$ & 0.95 & The required level is achieved \\
Parsimonious fit & Chisq/df $<3.00$ & 2.36 & The required level is achieved \\
\hline
\end{tabular}

The measurement model was performed with Maximum Likelihood Estimate. The tested model in CFA showed an acceptable fit (RMSEA=.06, CFI=.95, Chisq/df=2.36). The construct validity of the job stress measurement model had been achieved, indicating the accuracy of all the 24 items in measuring the job stress construct. The eight (8) components and their respective items are presented analytically in Table 2.

Table 2

The Confirmatory Factor Analysis (CFA) report summary for the measurement model

\begin{tabular}{|c|c|c|c|c|c|}
\hline Second Order & First Order & Item & Factor Loading (>.60) & $\mathrm{CR}(>.60)$ & $\operatorname{AVE}(>.50)$ \\
\hline \multirow[t]{24}{*}{ Job Stress } & \multirow[t]{5}{*}{ T1 } & T11 & 0.90 & \multirow[t]{5}{*}{0.93} & \multirow[t]{5}{*}{0.74} \\
\hline & & $\mathrm{T} 12$ & 0.95 & & \\
\hline & & $\mathrm{T} 13$ & 0.92 & & \\
\hline & & T14 & 0.79 & & \\
\hline & & $\mathrm{T} 15$ & 0.71 & & \\
\hline & \multirow{4}{*}{$\mathrm{T} 2$} & T21 & 0.73 & \multirow[t]{4}{*}{0.83} & \multirow[t]{4}{*}{0.55} \\
\hline & & $\mathrm{T} 22$ & 0.69 & & \\
\hline & & $\mathrm{T} 23$ & 0.83 & & \\
\hline & & $\mathrm{T} 24$ & 0.72 & & \\
\hline & \multirow{3}{*}{$\mathrm{T} 3$} & T31 & 0.87 & \multirow[t]{3}{*}{0.86} & \multirow[t]{3}{*}{0.66} \\
\hline & & T32 & 0.78 & & \\
\hline & & $\mathrm{T} 33$ & 0.79 & & \\
\hline & \multirow{3}{*}{$\mathrm{T} 4$} & T41 & 0.82 & \multirow[t]{3}{*}{0.87} & \multirow[t]{3}{*}{0.69} \\
\hline & & T42 & 0.91 & & \\
\hline & & $\mathrm{T} 43$ & 0.76 & & \\
\hline & \multirow{3}{*}{ T5 } & T51 & 0.78 & \multirow[t]{3}{*}{0.87} & \multirow[t]{3}{*}{0.70} \\
\hline & & T52 & 0.92 & & \\
\hline & & T53 & 0.80 & & \\
\hline & \multirow{2}{*}{ T6 } & T61 & 0.81 & \multirow{2}{*}{0.84} & \multirow[t]{2}{*}{0.72} \\
\hline & & T62 & 0.89 & & \\
\hline & \multirow{2}{*}{$\mathrm{T} 7$} & T71 & 0.86 & \multirow[t]{2}{*}{0.79} & \multirow[t]{2}{*}{0.65} \\
\hline & & $\mathrm{T} 72$ & 0.75 & & \\
\hline & \multirow{2}{*}{$\mathrm{T} 8$} & T81 & 0.93 & \multirow[t]{2}{*}{0.94} & \multirow[t]{2}{*}{0.88} \\
\hline & & T82 & 0.95 & & \\
\hline
\end{tabular}


The Average Variance Extracted (AVE) values were then measured to determine the convergent validity and reliability of this job stress construct. The AVE values which were higher than 0.50 indicated that the convergent validity had been achieved. Therefore, this measurement model met the convergent validity requirements, with AVE values ranging from 0.55 to 0.88 for all eight (8) components.

The validity test was implemented to measure the ability of the instrument to measure the construct of job stress, as well as to identify the item redundancy. The measurement indicated that the job stress measurement model was free from the overlapping or redundant items. Besides, the correlations between the components were lower than 0.85 , as showed in Table 3. The correlation values which were lower than 0.85 , indicated that the components were not redundant or having multicollinearity problem.

Table 3

Correlation values between components

\begin{tabular}{llll}
\hline & & & Estimate \\
\hline T1 & $<-->$ & T2 & 0.53 \\
T1 & $<-->$ & T3 & 0.58 \\
T1 & $<->$ & T4 & 0.50 \\
T1 & $<->$ & T5 & 0.56 \\
T1 & $<-->$ & T6 & 0.64 \\
T1 & $<-->$ & T7 & 0.44 \\
T1 & $<-->$ & T8 & 0.50 \\
T2 & $<-->$ & T3 & 0.57 \\
T2 & $<->$ & T4 & 0.48 \\
T2 & $<-->$ & T5 & 0.59 \\
T2 & $<->$ & T6 & 0.70 \\
T2 & $<-->$ & T7 & 0.45 \\
T2 & $<-->$ & T8 & 0.43 \\
T3 & $<->$ & T4 & 0.50 \\
T3 & $<-->$ & T5 & 0.57 \\
T3 & $<-->$ & T6 & 0.71 \\
T3 & $<->$ & T7 & 0.39 \\
T3 & $<-->$ & T8 & 0.60 \\
T4 & $<->$ & T5 & 0.59 \\
T4 & $<-->$ & T6 & 0.52 \\
T4 & $<-->$ & T7 & 0.44 \\
T4 & $<->$ & T8 & 0.32 \\
T5 & $<-->$ & T6 & 0.72 \\
T5 & $<->$ & T7 & 0.49 \\
T5 & $<-->$ & T8 & 0.51 \\
T6 & $<-->$ & T7 & 0.60 \\
T6 & $<->$ & T8 & 0.60 \\
T7 & $<-->$ & T8 & 0.32 \\
\hline & & &
\end{tabular}

Based on Table 4, the diagonal values in bold were the square roots of AVE value of job stress listed in Table 2. While the other values were the correlation between the respective components, the discriminant validity for all components was achieved as the diagonal values were higher than the values in its rows and columns. Referring to Table 
4, this study concluded that the discrimination validity of the job stress measurement model had been achieved.

Table 4

Discriminant validity index summary for job stress

\begin{tabular}{ccccccccc}
\hline & T1 & T2 & T3 & T4 & T5 & T6 & T7 & T8 \\
\hline T1 & $\mathbf{0 . 8 6}$ & & & & & & & \\
T2 & 0.53 & $\mathbf{0 . 7 4}$ & & & & & & \\
T3 & 0.58 & 0.57 & $\mathbf{0 . 8 1}$ & & & & & \\
T4 & 0.50 & 0.48 & 0.50 & $\mathbf{0 . 8 3}$ & & & & \\
T5 & 0.56 & 0.59 & 0.57 & 0.59 & $\mathbf{0 . 8 4}$ & & & \\
T6 & 0.64 & 0.70 & 0.71 & 0.52 & 0.72 & $\mathbf{0 . 8 5}$ & & \\
T7 & 0.44 & 0.45 & 0.39 & 0.44 & 0.49 & 0.60 & $\mathbf{0 . 8 1}$ & \\
T8 & 0.50 & 0.43 & 0.60 & 0.32 & 0.51 & 0.60 & 0.32 & $\mathbf{0 . 9 4}$ \\
\hline
\end{tabular}

Reliability

The composite reliability (CR) values which were greater than 0.60 for the job stress construct demonstrated that the reliability of the constructs had been achieved to the required level $(\mathrm{CR} \geq .60), \mathrm{T} 1=0.93, \mathrm{~T} 2=0.83, \mathrm{~T} 3=0.86, \mathrm{~T} 4=0.87, \mathrm{~T} 5=0.87, \mathrm{~T} 6=0.84$, $\mathrm{T} 7=0.79$ and $\mathrm{T} 8=0.94$. The $\mathrm{CR}$ components values between 0.79 and 0.93 and the $\mathrm{CR}$ construct's value of 0.90 indicated the level of reliability and internal consistency of the measured components representing the job stress construct. Besides, the AVE values exceeding 0.50 also indicated the reliability of the measurement model in measuring the job stress construct. The AVE achieved as the lowest AVE was T2 $=0.55$, followed by $\mathrm{T} 7=0.65, \mathrm{~T} 3=0.66, \mathrm{~T} 4=0.69, \mathrm{~T} 5=0.70, \mathrm{~T} 6=0.72, \mathrm{~T} 1=0.74$, while the highest AVE was $\mathrm{T} 8=0.88$.

\section{Modeling Job Stress as the Second Order Construct}

Job stress was a latent construct represented by an ellipse and was measured by eight (8) components namely $\mathrm{T} 1$ to T8, also represented by ellipses. Job stress had been modelled as a second-order construct that consisted of eight (8) components, while each component was measured using the certain number of items. The components were T1, T2, T3, T4, T5, T6, T7 and T8, described in Figure 2. The confirmatory factor analysis (CFA) was employed to test the measure of Job Stress construct were consistent with the nature of the construct itself. This study was interested to determine the factors that contributed to job stress and its respective measuring items. 


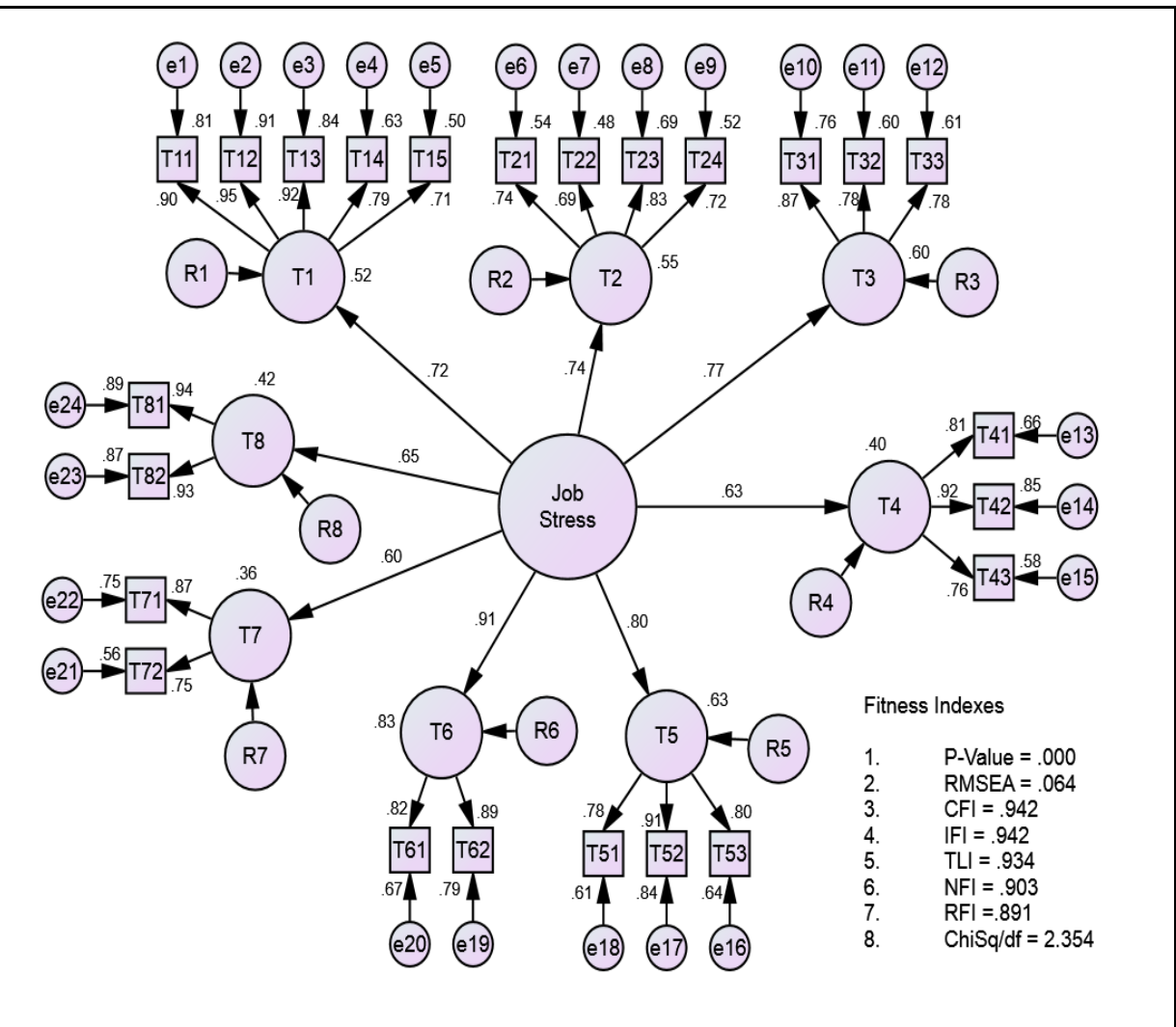

Figure 2

The measurement model for measuring job stress

The measurement model was performed and the tested model in CFA showed an acceptable fit $(\mathrm{RMSEA}=.06, \mathrm{CFI}=.94, \mathrm{Chisq} / \mathrm{df}=2.35)$. Thus, the construct validity of the job stress measurement model had been achieved, indicating the accuracy of all the 24 items measuring the job stress construct. The output in Figure 2 showed the factor loadings for the second order as well as the first-order construct.

The standardized estimate and squared multiple correlations were calculated through CFA. The standardized estimate indicated the factor loading for every item in the Job Stress measurement model. According to Dancey and Reidy (2011), the strength of a relationship was determined by the rule of thumb which stated the coefficient of $r=.00$ indicates no correlation between constructs instead of the coefficient value $r=1.00$ represents the perfect correlation. If the coefficient of correlation coefficient $r=.10$ to $r=.39$, the strength of the correlation is weak. The correlation value $r=.40$ to $r=.69$ shows a moderate correlation strength, while the correlation value $r=.70$ to $r=.99$ also highlights the strength of correlation was high, as in Table 5. 
Table 5

The correlation for items in job stress measurement model

\begin{tabular}{|c|c|c|c|c|}
\hline & & & $\mathrm{r}$ & Interpretation \\
\hline $\mathrm{T} 1$ & $<---$ & Job_Stress & 0.72 & High \\
\hline $\mathrm{T} 2$ & $<---$ & Job_Stress & 0.75 & High \\
\hline $\mathrm{T} 3$ & $<---$ & Job_Stress & 0.77 & High \\
\hline $\mathrm{T} 4$ & $<---$ & Job_Stress & 0.64 & Moderate \\
\hline T5 & $<---$ & Job_Stress & 0.80 & High \\
\hline T6 & $<---$ & Job_Stress & 0.91 & High \\
\hline $\mathrm{T} 7$ & $<---$ & Job_Stress & 0.60 & Moderate \\
\hline T8 & $<---$ & Job_Stress & 0.65 & Moderate \\
\hline $\mathrm{T} 11$ & $<---$ & $\mathrm{T} 1$ & 0.92 & High \\
\hline $\mathrm{T} 12$ & $<---$ & $\mathrm{T} 1$ & 0.95 & High \\
\hline $\mathrm{T} 13$ & $<---$ & $\mathrm{T} 1$ & 0.92 & High \\
\hline $\mathrm{T} 14$ & $<---$ & $\mathrm{T} 1$ & 0.79 & High \\
\hline $\mathrm{T} 15$ & $<---$ & $\mathrm{T} 1$ & 0.71 & High \\
\hline $\mathrm{T} 21$ & $<---$ & $\mathrm{T} 2$ & 0.74 & High \\
\hline $\mathrm{T} 22$ & $<---$ & $\mathrm{T} 2$ & 0.69 & Moderate \\
\hline $\mathrm{T} 23$ & $<---$ & $\mathrm{T} 2$ & 0.83 & High \\
\hline $\mathrm{T} 24$ & $<---$ & $\mathrm{T} 2$ & 0.72 & High \\
\hline $\mathrm{T} 31$ & $<---$ & $\mathrm{T} 3$ & 0.87 & High \\
\hline T32 & $<---$ & $\mathrm{T} 3$ & 0.78 & High \\
\hline $\mathrm{T} 33$ & $<---$ & $\mathrm{T} 3$ & 0.78 & High \\
\hline $\mathrm{T} 41$ & $<---$ & $\mathrm{T} 4$ & 0.81 & High \\
\hline $\mathrm{T} 42$ & $<---$ & $\mathrm{T} 4$ & 0.92 & High \\
\hline $\mathrm{T} 43$ & $<---$ & $\mathrm{T} 4$ & 0.76 & High \\
\hline T53 & $<---$ & $\mathrm{T} 5$ & 0.80 & High \\
\hline T52 & $<---$ & T5 & 0.92 & High \\
\hline T51 & $<---$ & T5 & 0.78 & High \\
\hline T62 & $<---$ & T6 & 0.89 & High \\
\hline T61 & $<---$ & T6 & 0.82 & High \\
\hline $\mathrm{T} 72$ & $<---$ & $\mathrm{T} 7$ & 0.75 & High \\
\hline $\mathrm{T} 71$ & $<---$ & $\mathrm{T} 7$ & 0.87 & High \\
\hline T82 & $<---$ & T8 & 0.94 & High \\
\hline $\mathrm{T} 81$ & $<---$ & $\mathrm{T} 8$ & 0.95 & High \\
\hline
\end{tabular}

(Source: Dancey \& Reidy, 2011)

Table 5 presented the factor loading for each item in the measurement model to measure the latent construct namely job stress, which explained the correlation between the job stress variables and the factors, and the key to understanding the underlying nature of that particular factor. All the items with the factor loading above 0.60 were maintained in the measurement model. The highest factor loading for the job stress construct was T6 (0.91) and the lowest was T4 (0.64). In each component, the highest factor loading for T1 was T12 (0.95), while in T2 was T23 (0.83) and in T3 was T31 (0.87). The highest factor loading for T4 was T42 (0.92), T5 with T52 (0.92), and T6 with T62 (0.89). For T7, the highest factor loading was T71 (0.87) and T8 with T81 (0.95).

The squared factor loadings indicated the percentage of the variance in the job stress variable was explained by every factor. The values shown in Table 6 indicated the 
squared multiple correlation values for that particular items. All the items indicated the $R^{2}$ values that higher than 0.40 , except for the $T 7$ component $\left(R^{2}=.36\right)$. Supposed, the $R^{2}$ value less than 0.40 should be deleted from the measurement model. However, since the fitness indexes for the measurement model already achieved the required level (Zainudin Awang, 2015), all the items were maintained.

Table 6

The squared multiple correlation values and effect size

\begin{tabular}{|c|c|c|}
\hline & Effect Size $\left(\mathrm{R}^{2}\right)$ & Percentage of Variance \\
\hline T8 & 0.42 & $42 \%$ \\
\hline $\mathrm{T} 7$ & 0.36 & $36 \%$ \\
\hline T6 & 0.83 & $83 \%$ \\
\hline T5 & 0.64 & $64 \%$ \\
\hline T4 & 0.40 & $40 \%$ \\
\hline T3 & 0.60 & $60 \%$ \\
\hline $\mathrm{T} 2$ & 0.56 & $56 \%$ \\
\hline $\mathrm{T} 1$ & 0.52 & $52 \%$ \\
\hline $\mathrm{T} 81$ & 0.89 & $89 \%$ \\
\hline T82 & 0.87 & $87 \%$ \\
\hline T71 & 0.75 & $75 \%$ \\
\hline $\mathrm{T} 72$ & 0.56 & $56 \%$ \\
\hline T61 & 0.67 & $67 \%$ \\
\hline T62 & 0.79 & $79 \%$ \\
\hline T51 & 0.61 & $61 \%$ \\
\hline T52 & 0.84 & $84 \%$ \\
\hline T53 & 0.65 & $65 \%$ \\
\hline $\mathrm{T} 43$ & 0.58 & $58 \%$ \\
\hline $\mathrm{T} 42$ & 0.85 & $85 \%$ \\
\hline T41 & 0.66 & $66 \%$ \\
\hline $\mathrm{T} 33$ & 0.61 & $61 \%$ \\
\hline $\mathrm{T} 32$ & 0.60 & $60 \%$ \\
\hline $\mathrm{T} 31$ & 0.76 & $76 \%$ \\
\hline $\mathrm{T} 24$ & 0.52 & $52 \%$ \\
\hline $\mathrm{T} 23$ & 0.69 & $69 \%$ \\
\hline $\mathrm{T} 22$ & 0.48 & $48 \%$ \\
\hline $\mathrm{T} 21$ & 0.54 & $54 \%$ \\
\hline $\mathrm{T} 15$ & 0.50 & $50 \%$ \\
\hline T14 & 0.63 & $63 \%$ \\
\hline $\mathrm{T} 13$ & 0.84 & $84 \%$ \\
\hline $\mathrm{T} 12$ & 0.91 & $91 \%$ \\
\hline T11 & 0.81 & $81 \%$ \\
\hline
\end{tabular}

The squared multiple correlation values showed in Table 5 indicated that T6 (technology training and support) component contributed to the highest variance in the job stress construct $\left(\mathrm{R}^{2}=.83\right)$, while the lowest variance contributed by the $\mathrm{T} 7$ 
component $\left(\mathrm{R}^{2}=.36\right)$, consisted of curriculum facilities and exposure constraints items. In the T1 (students misbehaviour) component, the highest variance came from item T12 (noisy students). The T2 (workload) component showed the highest variance from the T23 item which was the responsibility to the students. For the T3 (professional recognition) component, the highest variance was from T31 (less acknowledgment for the well-performed teachers), while for the T4 (time and resources constraints) component, the highest value of variance was from T42 (large number of students in a class). The T5 (interpersonal relationship) component showed the highest variance from the T52 item which was the parents' pressure. In the T6 (technology training and support) component, the highest variance came from item T62 (less technical support for the use of technology at school). For the T7 (facilities and curriculum exposure constraints) component, the highest variance was from T71 (lack of equipment and inadequate facilities), while for the T8 (technology literacy) component, the highest value of variance was from T81 (technology usage in teaching).

\section{DISCUSSION AND CONCLUSION}

The main purpose of this study was to confirm the structural equation model described factors contributing job stress among teachers in primary schools, as well as its reliability and validity. The results confirmed the reliability and validity of the proposed model on the sample of primary schools teachers. The overall analysis of this job stress model (a structural equation model), which recorded the influential factors on the axes of students misbehaviour, workload, professional recognition, time and resources constraints, interpersonal relationship, technology training and support, facilities and curriculum exposure constraints, and technology literacy indicated that the model has a very good fit.

\section{REFERENCES}

Abdul Said Ambotang, Norazizah Pilus, \& Andin, C. (2014). Hubungan Kerenah Pelajar dan Beban Tugas Dengan Tahap Stres Guru di Sekolah Menengah. Jurnal Kinabalu, 20, 103-124.

Anastasiou, S., \& Papakonstantinou, G. (2014). Factors Affecting Job Satisfaction, Stress and Work Performance of Secondary Education Teachers in Epirus, NW Greece. International Journal Management in Education, 8(1), 37-53.

Anis Salwa Abdullah, \& Siti Noor Ismail. (2018). Interaksi Kepimpinan Perkongsian dan Kepimpinan Sahih Guru Besar Terhadap Motivasi dan Tekanan Kerja Guru. Jurnal Kepimpinan Pendidikan, 5(1), 16-28. Retrieved from http://jupidi.um.edu.my/index.php/JUPIDI/article/view/10327/7350

Ashikia, O. A. (2010). Students and Teachers' Perception of the Causes of Poor Academic Performance in Ogun State Secondary Schools [Nigeria]: Implications for Couselling for National Development. European Journal of Social Sciences, 13(2), 229-242.

Azizi Yahaya, Jamaludin Ramli, \& Mazeni Ismail. (2010). Stres Dalam Kalangan Guru Sekolah Menengah di Empat Buah Negeri di Malaysia. Asia Pacific Journal of 
Educators and Education, 25, 103-136.

Boyle, G. J., Borg, M. G., Falzon, J. M., \& Jr., A. J. B. (1995). A Structural Model of the Dimensions of Teacher Stress. British Journal of Educational Psychology, 65(1), 49-67.

Collie, R. J., Shapka, J. D., \& Perry, N. E. (2012). School Climate and SocialEmotional Learning: Predicting Teacher Stress, Job Satisfaction, and Teaching Efficacy. Journal of Educational Psychology, 104(4), 1189-1204. http://doi.org/10.1037/a0029356

Dancey, C., \& Reidy, J. (2011). Statistics without maths for psychology. Book (5th ed.). Rotolito Lombarda, Italy: Prentice Hall.

Kamarulzaman Kamaruddin. (2007). Tekanan Kerja di Kalangan Guru Sekolah Menengah. Jurnal Kemanusiaan, 10, 104-118.

Karaj, S. (2012). Teacher stress in Albania: examining the role of students' classroom deviant behavior and other factors in the school context. In 1st Albania International Conference on Education (AICE) (pp. 317-324).

Nurul Izzah Abdul Samad, \& Zailina Hashim. (2010). Assessment of Stress and its Risk Factors among Primary School Teachers in the Klang Valley, Malaysia. Global Journal of Health Science, 2(2), 163-171.

Schaubman, A., Stetson, E., \& Plog, A. (2011). Reducing Teacher Stress by Implementing Collaborative Problem Solving in a School Setting. School Social Work Journal, 35(2), 72-93.

Shernoff, E. S., Mehta, T. G., Atkins, M. S., Torf, R., \& Spencer, J. (2011). A Qualitative Study of the Sources and Impact of Stress among Urban Teachers. School Mental Health, 3(2), 59-69. http://doi.org/10.1007/s12310-011-9051-z

Steinhardt, M. A., Jaggars, S. E. S., Faulk, K. E., \& Gloria, C. T. (2011). Chronic Work Stress and Depressive Symptoms: Assessing the Mediating Role of Teacher Burnout. Stress and Health, 27, 420-429. http://doi.org/10.1002/smi.1394

Tahir, A. Q. (2011). Effectiveness of Teaching Stress on Academic Performance of College Teachers in Pakistan. International Journal of Humanities and Social Science, 1(3), 123-129.

Zainudin Awang. (2015). SEM Made It Easy. Bandar Baru Bangi, Selangor: MPWS Rich Publication. 